\title{
PKM PENERAPAN TEKNOLOGI SISTEM INFORMASI MANAJEMEN DESA UNTUK MENINGKATKAN PELAYANAN YANG PRIMA KEPADA MASYARAKAT PADA DESA. PERBULAN, KEC. LAU BALANG, KAB. KARO, SUMUT
}

\author{
Ajulio Padly Sembiring ${ }^{1 *}$, Sharfina Faza ${ }^{2}$, Andam Lukcyhasnita ${ }^{3}$, Gunawan ${ }^{4}$ \\ 1,2,3,4 Jurusan Teknik Komputer dan Informatika, Politeknik Negeri Medan, 20155 Medan, Indonesia \\ e-mail : ajuliosembiring@polmed.ac.id ${ }^{1}$, sharfina.faza@gmail.com ${ }^{2}$, \\ andamlukcyhasnita@polmed.ac.id ${ }^{3}$, gunawan@polmed.ac.id ${ }^{4}$
}

\begin{abstract}
Abstrak: Desa Perbulan, Kecamatan Lau Baleng, Kabupaten Karo, Provinsi Sumatra Utara membutuhkan kehadiran perguruan tinggi dalam meningkatkan kualitas kinerja dan pelayanan perangkat desa terhadap masyarakatnya. Dimana dewasa ini seluruh aktifitas pekerjaan sudah menggunakan komputer yang tentunya memudahkan dan menghemat biaya dan waktu dalam setiap pekerjaan, namu di Desa Perbulan Kab. Karo masih minim penggunaan kumputer dan sistem komputer dalam melayani masyarakat yang berakibat labatnya setiap proses administrasi yang dilakukan oleh masyarakat kepada pemerintahan desa. Tentutnya kondisi ini sangat merugikan masyarakat dimana masyarakat harus meniggalakan pekerjaan berhari-hari hanya demi mengurus selembar surat di kantor desa. Dari msalah ini kami menawarkan pembangunan Sistem Informasi Manajeman Desa untuk memudahkan seluruh pekerjaan perangkat desa untuk melayanin masyarakan desa, dimana sistem yang akan dibangun berbasis web yang akan di online-kan dan dapat di akses oleh seluruh masyarakat yang akan menghasilkan transparansi pemerintah desa terhadap mesyarakat dan akan menghasilkan kepercayaan masyarakat terhapat pemerintahan desa.
\end{abstract} Kata Kunci: Sistem, Website, Online, Digitalisasi

\begin{abstract}
Perbulan Village, Lau Baleng Subdistrict, Karo Regency, North Sumatra Province requires the presence of universities in improving the quality of performance and services of village officials to the community. Where today all work activities are already using computers which of course make it easier and save costs and time in every job, but in the Perbulan Village, Kab. Karo still lacks the use of computers and computer systems in serving the community which results in the profit of every administrative process carried out by the community to the village government. Of course, this condition is very detrimental to the community where people have to leave work for days just to take care of a letter at the village office. From this problem, we offer the development of a Village Management Information System to facilitate all the work of village officials to serve the village community, where the system to be built is web-based which will be online and accessible to the whole community which will result in village government transparency towards the community and will generate public trust in the village government.
\end{abstract}

Keywords: System, Website, Online, Digitization

\section{Pendahuluan}

Perkembangan teknologi sistem informasi saat ini sangatlah pesat dimana hampir seluruh aspek pekerjaan dibantu dengan sistem informasi yang dibangun berbasis web (Sudirman et al., 2020). Pada dasarnya sistem adalah sekelompok unsur yang erat hubungannya satu dengan yang lain, yang berfungsi bersama-sama untuk mencapai tujuan tertentu (Sophian, 2016) dan Informasi adalah data yang diolah menjadi bentuk yang lebih berguna dan lebih berarti bagi yang menerimanya (Nugraha, Pramukasari, \& Sumaryana, 2017). Sumber dari informasi adalah data (Wahyono, 2004), data merupakan bentuk jamak dari bentuk tunggal data atau item (Yusuf, SPi, Daris, \& SPi, 2019). Data adalah kenyataan yang menggambarkan sesuatu yang terjadi pada saat tertentu (Rompas, Pangemanan, \& Kalalo, 2018). Tentunya pengembangan sistem informasi sangatlah diperlukan untuk 
meningkatkan kualitas kerja aparatur desa perbulan yang menjadi mitra pada pengabdian masyarakat kali ini.

Pemerintahan desa adalah garda terdepan (Lambuaso, Pangemanan, \& Monintja, 2020) yang langsung berinteraksi dengan masyarakat dalam memberikan pelayanan dan penyuluhan terkait hal-hal yang wajib di informasikan kepada manyarakat. Tentunya dalam hal administrasi sangatlah penting untuk dilakukan secara cermat dan tepat (Rahman, 2017) karena masyarakat sangat mengharapkan pelayanan yang prima yang diberikan pemerintahan desa terhadapnya.

1. Mitra adalah Desa Perbulan yang terletak di Kecamatan Lau Balang Kabupaten Karo Provinsi Sumatra Utara. Tidak lengkapnya pengarsipan dokuman dan pendataan penduduk, surat menyurat masih dikerjakan secara manual dan memakan waktu lama. 2. Dengan kondisi saat ini layanan terhadap masyarakat sangat tidak baik dan membutuhkan waktu yang lama, pelayanan yang kurang baik akan berakibat tingkat kepercayaan akan menurun dan kepedulian otomatis akan berkurang, kondisi ini sangat bebahaya jika terus terjadi kehidupan bermasyarakat akan teganggu.

3. Persoalan yang dihadapi kurangnya sumber daya pada desa yang mampu mengoprasikan komputer, tidak efektif dan efisin pekerjaan yang dilakaukan perangkat desa.

4. Permasalahan khusus yang dihadapi tidak memiliki website desa, tidak memiliki sistem terkomputerisasi.

Pada kegiatan pengabdian ini persoalan prioritas yang disepakati untuk diselesaikan selama pelaksanaan pengabdian adalah mendigitalisasi proses surat menyurat, pengarsipan dokumen, pendataan penduduk dan pembangunan sistem informasi desa, dari beberapa aspek yang telah disepakati Bersama Desa Perbulan diantaranya :

1. Aspek Manajerial Desa Perbulan dalam pengelolaan kegiatan surat menyurat dan pengarsipan dokumen desa.

2. Aspek Penerapan teknologi sistem informasi desa dan sistem terdigitalisasi berbasis web.

3. Aspek peningkatan dan efektifitas hasil laporan yang di hasilkan oleh sistem dengan alat bantu printer dan scan.

Pada kegiatan pengabdian kepada masyarakat pengabdian menawarkan untuk menyelesaikan permasalahan yang dihadapi mitra secara sistematis sesuai dengan prioritas permasalahan yang dimiliki oleh desa perbulan.

1. Berkaitan aspek manajerial desa Perbulan dalam pengelolaan kegiatan surat menyurat dan pengarsipan dokumen desa dengan permasalah terkait digitalisasi proses solusi yang di tawarkan adalah pembangunan sistem pengarsipan dimana dokumen di jadikan softcopy dengan cara di scan dan arsipkan dalam bentuk sotcopy kedalam sistem yang dibangun.

2. Sistem atau aplikasi yang dibangun akan di tempatkan di hosting atau server online dimana perangkat desa dapat mengakses sistem dengan terkoneksi terlebih dahulu ke jaringan internet dan memasukkan user dan password untuk masuk kedalam sistem dan menggunakan sistem tersebut.

3. Melakukan pelatihan peningkatan kapasitas perangkat desa dengan pelatihan penggunaan perangkat komputer yang digunakan untuk pengelolaan administrasi berbasis web desa. 


\section{Metode}

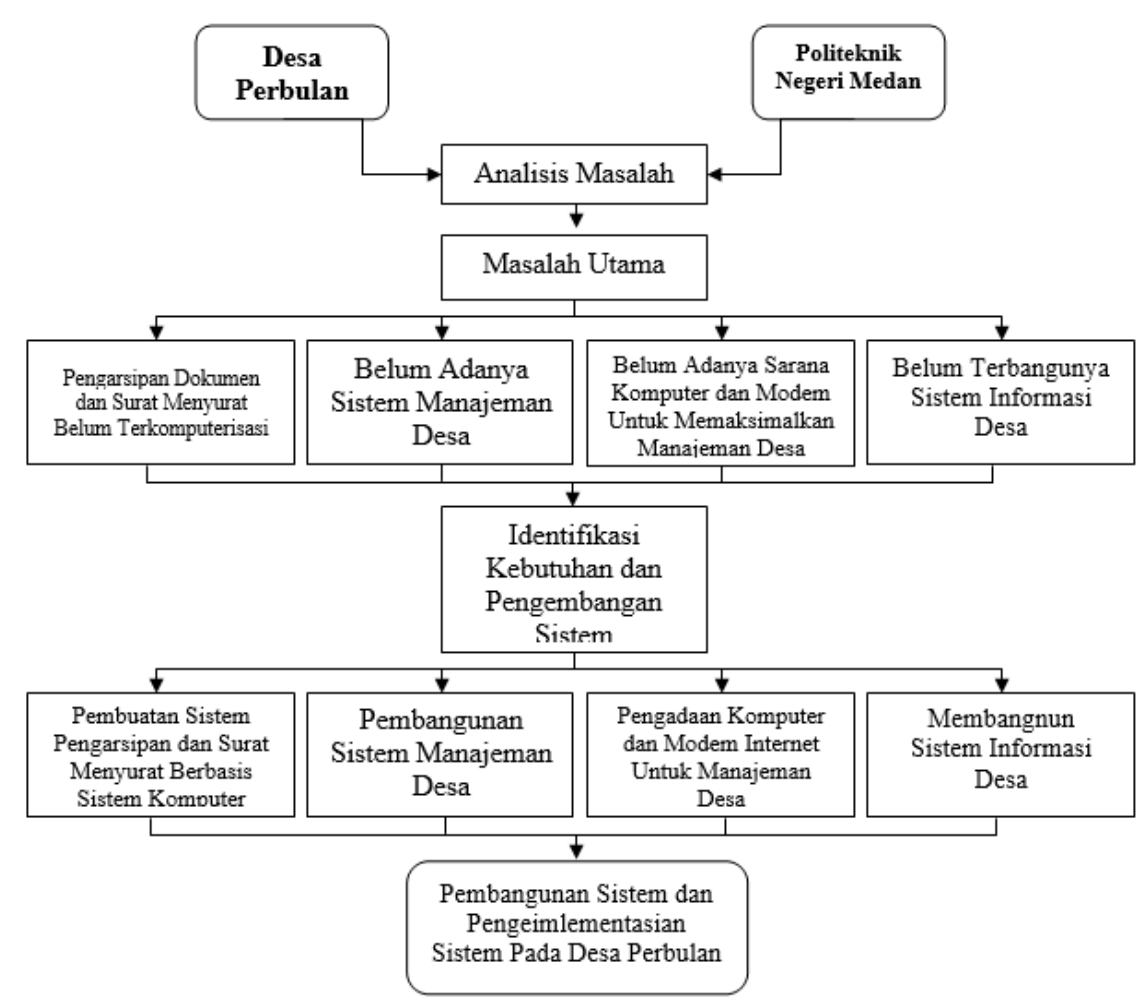

Gambar 1. Metodologi Pelaksanaan Pengabdian

Dalam tahapan pengabdian awalnya dilakukan Analisa masalah pada mitra Desa Perbulan bersama tim pengabdi dari Politeknik Negeri Medan. Setelah dilakukan analisis masalah dan ditemukan apa saja permasalahan yang dimiliki oleh Desa Perbulan. Tahapan selanjutnya adalah mengidentifikasi permasalahan yang dimiliki oleh desa untuk dirancang dan diberikan Solusi melalui tahapan identifikasi kebutuhan yang akan diberikan kepada desa Perbulan. Selanjutnya tahapan perancangan, pembuatan sistem dan pelatihan manajeman administrasi desa untuk mendukung kebutuhan desa yg dikerjakan di Lab Komputer milik Politeknik Negeri Medan oleh tim pengabdi. Setelah sistem selesai dibangun kemudian dilakukan serah terima dan pelatihan terhadap desa Perbulan untuk penggunaan sistem yang telah dibuat oleh tim pengabdi. Dan akan diberikan pendampingan selama 1 bulan hingga desa Perbulan dapat memanfaatkan teknologi tersbut dengan baik tanpa kendala.

\section{Hasil dan Pembahasan}

Mitra yang terlibat dalam program ini adalah Desa Perbulan, Kecamatan Lau Baleng, Kabupaten Karo, Provinsi Sumatra Utara. Dengan permasalahan yang ada yaitu belum adanya sistem manajemen desa dan sistem informasi desa, sehingga tim pengabdian membangun sebuah sistem manajemen desa berbasis teknologi untuk memudahkan kegiatan sarana dan prasarana di kantor desa. Selain memberikan suatu sistem kepada desa, tim pengabdian juga memberikan pelatihan pengelolaan sistem kepada beberapa pegawai atau admin pada kantor desa, dan memberikan beberapa alat tambahan seperti printer dan modem untuk sebagai pendukung kegiatan desa. 


\section{Tahap Persiapan}

Tahap ini terdiri dari beberapa langkah sebagai berikut:

1. Melakukan wawancara kepada mitar, tentang apa saja permasalahan yang dihadapi

2. Melakukan identifikasi kebutuhan

3. Pembuatan sistem pengarsipan dan sistem manajemen desa

4. Uji Coba sistem yang dibuat

5. Setting dan uji coba kembali sistem yang akan diberikan kepada mitra

\section{Tahap Pelaksanaan}

Dalam pelaksanaan pengabdian ini, sesi pertama merupakan sesi sosialisasi kepada pada perangkat desa terhadap sistem yang dibangun, tujuan dan manfaat yang akan didapat saat setelah menggunakan sistem. Pada sesi kedua, tim pengabdian melakukan pelatihan terhadap admin pada kantor desa untuk dapat melakukan pengelolaan terhadap data-data seperti data penduduk desa sampai kegiatan surat menyurat yang dapat dimudahkan dengan menggunakan sistem yang dibangun.

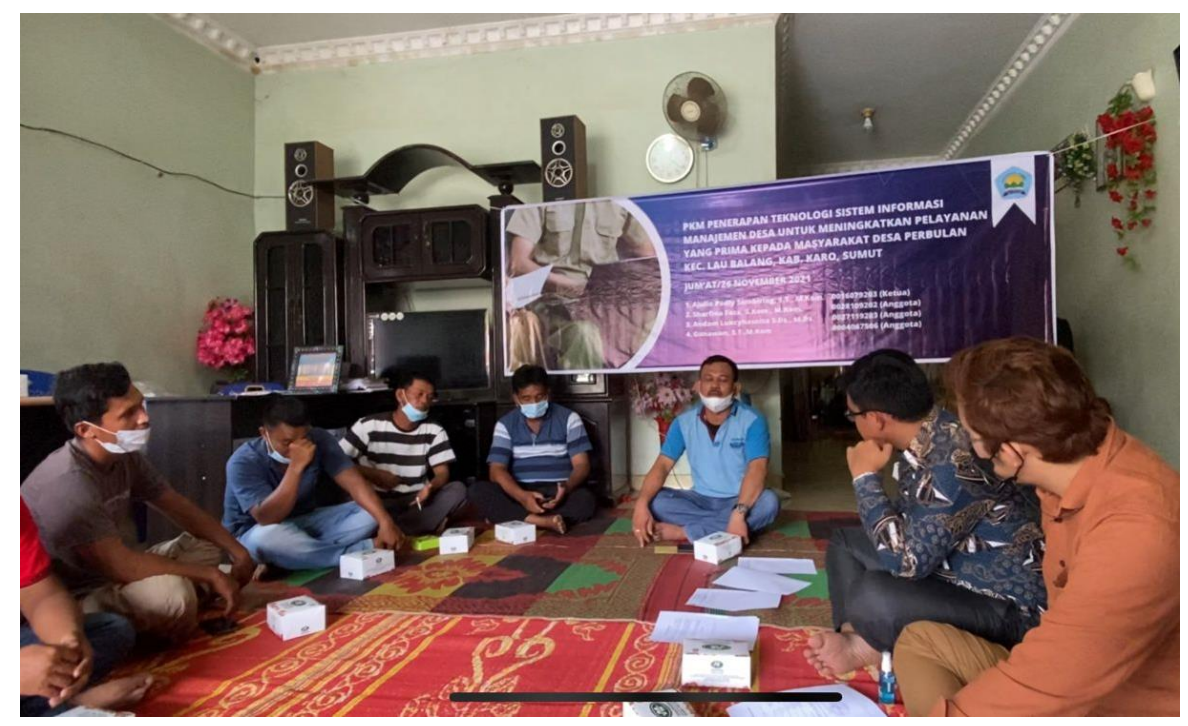

Gambar 1. Suasana Pelaksanaan PKM

\section{Tahap Monitoring}

Monitoring program dilakukan sejak awal dimulainya kegiatan ini dari tahap persiapan, proses pelaksanaan, sampai tahap akhir kegiatan (Ariefni \& Legowo, 2018). Setiap akhir tahapan kegiatan dilakukan monitoring guna mengetahui apakah pelaksanaan program sesuai dengan rencana program yang telah dibuat. Kegiatan evaluasi dilakukan berdasarkan hasil monitoring dan temuan dilapangan untuk selanjutnya dilakukan tindak lanjut melalui perbaikan (PONGOLIU, Saerang, \& Manossoh, 2017).

\section{Tahap Evaluasi}

Evaluasi kegiatan ini dilakukan setelah program selesai dilaksanakan. Target utama pasca kegiatan pengabdian ini yang ingin dicapai adalah Desa perbulan dapat mengelola kegiatan surat menyurat dan pengarsipan dokumen desa secara digitalisasi dengan adanya sistem 
pengarsipan dimana dokumen di jadikan softcopy dengan cara di scan dan arsipkan dalam bentuk sotcopy kedalam sistem yang dibangun.

Pada tahap evaluasi, feedback dari para perangkat desa adalah sebagai berikut:

1. Seluruh peserta $(100 \%)$ berpendapat bahwa sistem yang diberikan sangat bermanfaat dan memudahkan dalam proses surat menyurat.

2. Seluruh peserta $(100 \%)$ berpendapat bahwa sistem yang diberikan sangat membantu para perangkat desa dalam pendataan warga desa.

3. Seluruh peserta $(100 \%)$ berpendapat bahwa penjelasan tim pengabdian saat melakukan sosialisasi sangat mudah dipahami

4. Seluruh peserta $(100 \%)$ berpendapat bahwa penjelasan tim pengabdian saat melakukan pelatihan sangat mudah dipahami

5. Seluruh peserta $(100 \%)$ menyatakan bahwa kegiatan ini sangat dibutuhkan oleh perangkat desa dan bahkan dapat dilanjutkan

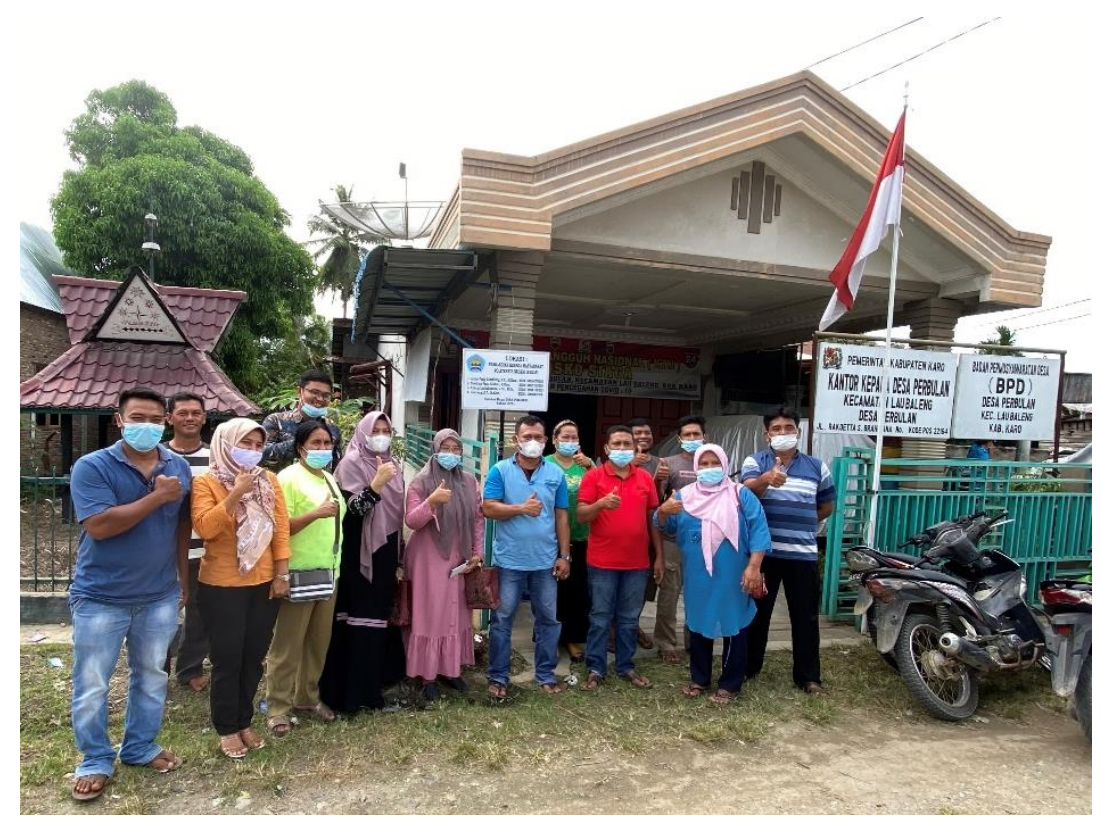

Gambar 2. Foto tim PKM bersama Peserta

\section{Kesimpulan}

Kegiatan pengabdian kepada masyarakat ini berupa memberikan sebuah sistem informasi manajemen desa yang dapat memudahkan perangkat desa dalam melakukan pendataan masyarakat desa serta memudahkan dalam kegiatan surat-menyurat yang pada awalnya dilakukan secara manual. Kegiatan pengabdian masyarakat ini telah selesai dilaksanakan dan Desa Perbulan sebagai mitra telah mendapatkan manfaat dari kegiatan ini, selain adanya sistem informasi manajemen desa, tim pengabdian juga memberikan beberapa alat guna pendukung sarana dan prasarana kantor desa, yaitu berupa modem dan printer.

\section{Ucapan Terima Kasih}

Kegiatan pengabdian kepada masyarakat ini dibiayai oleh DIPA Politeknik Negeri Medan, sesuai Surat Perjanjian Pelaksanaan Kegiatan Nomor: B/625/PL5/PM.01.00/2021 dengan tanggal 25 Oktober 2021. Atas dukungan finansial ini, penulis mengucapkan terima. 


\section{Daftar Pustaka}

\section{Jurnal:}

Ariefni, D. F., \& Legowo, M. B. (2018). Penerapan Konsep Monitoring Dan Evaluasi Dalam Sistem Informasi Kegiatan Mahasiswa Di Perbanas Institute Jakarta. JUTISI (Jurnal Teknik Informatika dan Sistem Informasi), 4(3), 422-432-422-432.

Lambuaso, D. H., Pangemanan, S., \& Monintja, D. (2020). INOVASI PEMERINTAH DESA DALAM MENINGKATKAN PEMBANGUNAN DESA ESSANG SELATAN. JURNAL EKSEKUTIF, 2(5).

Nugraha, A. R., Pramukasari, G., \& Sumaryana, Y. (2017). Sistem Informasi Akademik Sekolah Berbasis Web Di Sekolah Menengah Pertama Negeri 11 Tasikmalaya. Jurnal Manajemen Informatika (JUMIKA), 4(2).

PONGOLIU, R. R., Saerang, D., \& Manossoh, H. (2017). Analisis Kendala Penyelesaian Tindak Lanjut Hasil Pemeriksaan BPK Pada Pemerintah Provinsi Gorontalo. JURNAL RISET AKUNTANSI DAN AUDITING" GOODWILL", 8(1).

Rahman, M. (2017). IImu administrasi(Vol. 1): Sah Media.

Rompas, R. A., Pangemanan, S., \& Kalalo, M. (2018). Evaluasi efektivitas pengendalian intern sistem informasi akuntansi penggajian rsup. Prof. Dr. RD Kandou manado. Going concern: jurnal riset akuntansi, 13(02).

Sophian, S. (2016). Sistem Informasi Pengolahan Data Pada Koperasi Rezeky. Jurnal Teknologi Informasi dan Pendidikan, 9(1), 48-55.

\section{Buku :}

Sudirman, A., Muttaqin, M., Purba, R. A., Wirapraja, A., Abdillah, L. A., Fajrillah, F., . . Simarmata, J. (2020). Sistem Informasi Manajemen: Yayasan Kita Menulis.

Wahyono, T. (2004). Sistem Informasi. Yogyakarta: Graha IImu.

Yusuf, M., SPi, M., Daris, L., \& SPi, M. (2019). Analisis Data Penelitian: Teori \& Aplikasi dalam Bidang Perikanan: PT Penerbit IPB Press. 